\title{
Pasture characteristics of Italian ryegrass and milk production under different management strategies
}

\author{
Marcolino Frederico Miguel(1), Henrique Mendonça Nunes Ribeiro Filho(1), Steben Crestani(1), \\ Fabiana da Rocha Ramos(1) and Tereza Cristina Moraes Genro(2)
}

\begin{abstract}
(1)Universidade do Estado de Santa Catarina, Centro de Ciências Agroveterinárias, Avenida Luiz de Camões, no 2.090, Conta Dinheiro, CEP 88520-000 Lages, SC, Brazil. E-mail: marcolino_miguel@yahoo.com.br, a2hrf@cav.udesc.br, stebencrestani@hotmail.com, fabiana@veterinaria.med (2)Embrapa Pecuária Sul, Rodovia BR 153, Km 603, Vila Industrial, Caixa Postal 242, CEP 96401-970 Bagé, RS, Brazil. E-mail: cristina@cppsul.embrapa.br
\end{abstract}

\begin{abstract}
The objective of this work was to assess the effects of the sward structure of Italian ryegrass (Lolium multiflorum), during the first grazing cycle, on its morphological and bromatological characteristics throughout the growing season, and on the performance of dairy cows. The treatments consisted of two structures obtained as a function of canopy-light interception: high-light interception (HLI) and low-light interception (LLI), with different pre-grazing heights in the first grazing cycle. Pasture was managed under rotational grazing with a herbage allowance not below $30 \mathrm{~kg}$ dry matter (DM) per cow per day. Three grazing cycles, with a grazing interval of 30 days, were evaluated. Pre-grazing herbage mass was greater $\left(2,240 \mathrm{vs.} 1,656 \mathrm{~kg} \mathrm{ha}^{-1} \mathrm{DM}\right)$, but the proportion of leaf blades was smaller ( 0.35 vs. 0.43 ) for HLI swards. Neutral detergent fiber (NDF) content and organic matter digestibility (OMD) were similar between treatments in the first grazing cycle, but in the second and third ones NDF was greater, and OMD lower, for the HLI swards. Milk yields were greater for cows grazing LLI swards (19.4 vs. $21.1 \mathrm{~kg}$ per day). Initial grazing with $90 \%$ of light interception promotes greater nutritional value in the subsequent cycles.

Index terms: Lolium multiflorum, dairy cow, herbage intake, sward structure.

\section{Características da pastagem de azevém anual e produção de leite sob diferentes estratégias de manejo}

\begin{abstract}
Resumo - O objetivo deste trabalho foi avaliar os efeitos da estrutura do pasto de azevém anual (Lolium multiflorum), no primeiro ciclo de pastejo, sobre suas características morfológicas e bromatológicas, ao longo da estação de crescimento, e sobre o desempenho de vacas leiteiras. Os tratamentos consistiram de duas estruturas, obtidas em função da intensidade de interceptação luminosa do dossel: alta interceptação luminosa (AIL) e baixa interceptação luminosa (BIL), com diferentes alturas de pasto na entrada para o primeiro ciclo de pastejo. A pastagem foi manejada sob lotação intermitente com oferta não inferior a $30 \mathrm{~kg}$ de matéria seca (MS) por vaca por dia. Três ciclos de pastejo, com intervalos de 30 dias entre eles, foram avaliados. A massa de forragem pré-pastejo foi superior (2.240 vs. $1.656 \mathrm{~kg} \mathrm{ha}^{-1}$ de MS), mas a proporção de lâminas foliares foi inferior $(0,35$ vs. 0,43$)$ nos pastos AIL. Os teores de fibra em detergente neutro (FDN) e a digestibilidade da matéria orgânica (DMO) foram semelhantes, no primeiro ciclo de pastejo, mas, no segundo e no terceiro, o FDN foi superior e a DMO inferior nos pastos AIL. A produção de leite foi superior nas vacas dos pastos BIL (19,4 vs. $21,1 \mathrm{~kg}$ por dia). O início do pastejo com $90 \%$ de interceptação luminosa promove maior valor nutricional nos ciclos subsequentes.
\end{abstract}

Termos para indexação: Lolium multiflorum, vaca leiteira, estrutura do pasto, consumo de forragem.

\section{Introduction}

The efficiency of production systems for grazing animals is a function of the ingested herbage quality and quantity, which are strongly correlated to the adopted forage species and management practices (Hopkins \& Wilkins, 2006). In terms of quantity, the ratio between herbage allowance and daily intake is well known (Peyraud et al., 1996). However, the pasture management designed to supply forage, without limiting intake, usually implies on reduced grazing efficiency of accumulated aerial biomass, which may decrease pasture quality throughout its growing season (Purcell et al., 2011). 
Some management strategies have been studied, mainly those involving perennial ryegrass pastures in temperate climate regions, in order to achieve an optimal herbage ingestions per cow and per hectare (Delaby \& Peyraud, 2009). Among these, are the hasting date of first grazing (O'Donovan et al., 2004; Kennedy et al., 2006, 2007) and the increased defoliating frequencies with reduced intervals between grazing cycles and increasing number of cycles (McEvoy et al., 2009; Curran et al., 2010; Roca-Fernandez et al., 2011). In both cases, milk yield can increase up to $2.0 \mathrm{~kg}$ per cow and more than $1,300 \mathrm{~kg} \mathrm{ha}^{-1}$. However, little is still known about the effects of aerial biomass availability before the first grazing cycle on milk yield during the growing cycle of the most common winter forage species, such as Italian ryegrass (Lolium multiflorum Lam.), in subtropical climate regions. Therefore, it is relevant to know if Italian ryegrass pastures with larger proportion of leaf blades at the beginning of the first grazing cycle would allow for the maintenance of this parameter throughout sucessive cycles and if it has positive consequences on herbage intake and fat-corrected milk yields.

The objective of this work was to assess the effects of the sward structure of Italian ryegrass (Lolium multiflorum) during the first grazing cycle on its morphological and bromatological characteristics throughout the growing season, and on the performance of dairy cows.

\section{Materials and Methods}

The experiment was carried out at the Universidade do Estado de Santa Catarina, Lages, SC, Brazil (27²7'4"S and $50^{\circ} 18^{\prime} 26^{\prime \prime} \mathrm{W}$, at $920-\mathrm{m}$ altitude), during the 2010 ryegrass growing season (from August to October). The soil was classified as a fine-loamy typical Haplumbrept. Two uniform 1.2 ha paddocks were used for each treatment and were split into three 0.4 ha replicates. It was used the rotational grazing method with electric fence-enclosed areas, inside each replicate slice, for four-day occupancy periods, and a herbage allowance not below $30 \mathrm{~kg}$ of dry matter (DM) per cow.

The treatments consisted of two structures obtained as a function of canopy light interception in the first grazing cycle: high-light interception (HLI) and low-light interception (LLI). HLI swards were first grazed when light interception reached 95\%, whereas LLI swards were first grazed when light interception had reached $90 \%$. Light interception was measured with a ceptometer Accupar LP-80, (Decagon Devices, Inc., Pullman, WA, USA). In order to simultaneously graze both treatments, HLI swards were fertilized with $50 \mathrm{~kg} \mathrm{ha}^{-1}$ of $\mathrm{N}$, as ammonium nitrate, as soon as tillering had began. Seven days later, LLI swards received the same amount of nitrogen. LLI and HLI swards were first grazed 21 and 28 days after $\mathrm{N}$ fertilization, respectively.

Twelve Holstein dairy cows were assigned to two uniform six-cow groups (two cows per replicate per area), according to milk yield $(23.1 \pm 6.7 \mathrm{~kg}$ per day), lactation stage (114 \pm 70 days), body weight $(569.3 \pm 40.3 \mathrm{~kg})$, and amount of lactations $(2.5 \pm 1.1)$. Three grazing cycles were monitored during the experiment, with a rest period of 30 days. For each cycle, animals stayed in the experimental area for 12 days, without any supplementation. Measurements were taken during the four last days of each cycle. Each area was fertilized immediately after each cycle, with $50 \mathrm{~kg} \mathrm{ha}^{-1}$ of $\mathrm{N}$ supplied as ammonium nitrate. In the grazing intervals, all animals stayed, in one single group, in an overseeded ryegrass paddock: ryegrass was overseeded with a mix of temperate climate forage species (Festuca arundinacea Schreb., Trifolium repens L., and Trifolium pretense L.).

Pre-grazing biomass was estimated by the compressed height, measured with a F200 rising plate meter (Farmworks, Feilding, New Zealand), and by the DM amount present at the disk area $\left(0.1 \mathrm{~m}^{2}\right)$. Before and after each grazing cycle, regression equations were obtained for biomass estimation $\left(\mathrm{kg} \mathrm{ha}^{-1} \mathrm{DM}\right)$ as a function of grass height $(\mathrm{cm})$. For this, five points by treatment were cut with scissors at ground level. After manual removal of soil and roots, the samples were oven-dried for 72 hours at $60^{\circ} \mathrm{C}$.

Extended tiller and sheath heights were measured before and after grazing in the last four days of each cycle. Representative forage samples were taken at soil level from the same paddocks before grazing. Samples were separated into two subsamples: one was cut at the average post-grazing extended tiller height, with its upper portion oven-dried for 72 hours at $60^{\circ} \mathrm{C}$, and was stored for chemical composition assessment; and the other was used for morphological classification and assessment of the mass ratios of leaf blades, stems (stems and pseudostems), dead material, and others.

The protocol for forage sampling in laboratory was performed according to Ribeiro Filho et al. (2003). The

Pesq. agropec. bras., Brasília, v.47, n.6, p.863-868, jun. 2012 
offered biomass underestimated the nutritional value of forage intake. As described, the fraction selected for analysis was always higher than the residual tiller height, which was identified in individual paddocks.

Animals were milked twice a day. Individual milk yield was measured daily for both milking times (at $7 \mathrm{~h} 30$ a.m. and 4 h30 p.m.). Samples were taken in order to assess milk fat and protein contents during the last four days of each evaluated cycle for both milking times. Milk samples were pooled by day and stored at $4^{\circ} \mathrm{C}$ with the preservative bromopol tablet, (D \& F Control Systems, Inc., San Ramon, CA, USA) before being analyzed for fat and protein contents using infrared analysis, method no 972.160 (Horwitz, 2000). Individual forage intake was assessed from body weight and milk yield and composition, as proposed by Baker (2004). Animals were weighed once a week.

Mineral matter content was assessed by a 4-hour muffle furnace calcination at $550^{\circ} \mathrm{C}$. Forage and feces samples were used for crude protein $(\mathrm{CP})$ measurements using the Kjeldahl method. Acid detergent fiber (ADF) was measured according to Robertson \& Van Soest (1981), and neutral detergent fiber (NDF) to Van Soest et al. (1991). NDF and ADF contents included ash trace residues. Forage organic matter digestibility was estimated from $\mathrm{CP}$ content of feces and forage and
ADF contents of feces, as described by Ribeiro Filho et al. (2003).

Data was subjected to analysis of variance according to a mixed model with repeated measurements in time, using the SAS package (Littell et al., 1998). The paddock was the experimental unit chosen for assessments and calculations. Effects from the experimental treatment, grazing cycle, and treatment $\mathrm{x}$ cycle interactions were treated as fixed, whereas the paddock was considered as random data. Measurements taken from animals (herbage intake, milk yield, milk fat, and protein contents) used initial milk yield as a covariate.

\section{Results and Discussion}

There was no interaction between sward types and grazing cycles for pre-grazing herbage mass, pre-grazing sward height, and morphological composition (Table 1). Therefore, these results were presented and discussed based on the averages of each factor (type of pasture and cycle).

Sward height was higher for HLI than for LLI swards and increased in the second and third cycles in comparison to the first cycle. Regardless of extended tiller height and sheath, the responses observed were indirectly related to the proportion of blades in the

Table 1. Effects of grazing management (GM) and grazing cycle (GC) on the characteristics of herbage offered to dairy cows grazing Italian ryegrass (Lolium multiflorum) ${ }^{(1)}$.

\begin{tabular}{|c|c|c|c|c|c|c|c|c|c|c|}
\hline \multirow[t]{2}{*}{ Parameter } & \multicolumn{2}{|c|}{ Cycle 1} & \multicolumn{2}{|c|}{ Cycle 2} & \multicolumn{2}{|c|}{ Cycle 3} & \multirow[t]{2}{*}{$\mathrm{SE}$} & \multicolumn{3}{|c|}{ Significance } \\
\hline & HLI & LLI & HLI & LLI & HLI & LLI & & GM & GC & GM vs. GC \\
\hline & \multicolumn{10}{|c|}{ Pre-grazing sward height $(\mathrm{cm})$} \\
\hline Rising plate meter & 8.3 & 6.6 & 16.2 & 12.4 & 17.7 & 13.1 & 0.5 & $* * *$ & $* * *$ & $\mathrm{~ns}$ \\
\hline Extended tiller & 45.9 & 35.3 & 51.8 & 44.1 & 56.7 & 51.6 & 0.9 & $* * *$ & $* * *$ & $\mathrm{~ns}$ \\
\hline \multirow[t]{2}{*}{ Extended sheath } & 20.8 & 15.9 & 38.7 & 22.8 & 44.3 & 39.1 & 1.4 & $* *$ & $* * *$ & ns \\
\hline & \multicolumn{10}{|c|}{ Morphological composition ( $\left.\mathrm{g} \mathrm{kg}^{-1} \mathrm{DM}\right)$} \\
\hline Live lamina & 592 & 645 & 286 & 431 & 164 & 221 & 12.2 & $* * *$ & $* * *$ & ns \\
\hline \multirow[t]{2}{*}{ Live sheath and stem } & 326 & 337 & 629 & 515 & 703 & 669 & 13.3 & $*$ & $* * *$ & $\mathrm{~ns}$ \\
\hline & \multicolumn{10}{|c|}{ Pre-grazing herbage mass $\left(\mathrm{kg} \mathrm{ha}^{-1} \mathrm{DM}\right)$} \\
\hline Total & 1,111 & 710 & 3,218 & 2,105 & 3,124 & 2,444 & 48.1 & $* * *$ & $* * *$ & ns \\
\hline \multirow[t]{2}{*}{$\underline{\text { Live lamina }}$} & 659 & 458 & 911 & 914 & 512 & 543 & 33.0 & ns & $* * *$ & ns \\
\hline & \multicolumn{10}{|c|}{ Chemical composition ( $\left.\mathrm{g} \mathrm{kg}^{-1} \mathrm{DM}\right)$} \\
\hline Dry matter $\left(\mathrm{g} \mathrm{kg}^{-1}\right)$ & 165 & 178 & 222 & 174 & 205 & 210 & 5.19 & ns & $* *$ & $*$ \\
\hline Organic matter & 902 & 900 & 925 & 918 & 938 & 935 & 1.97 & ns & $* * *$ & ns \\
\hline Crude protein & 216 & 258 & 147 & 196 & 148 & 171 & 5.4 & $* * *$ & $* * *$ & ns \\
\hline Neutral detergent fiber & $331 \mathrm{a}$ & $332 \mathrm{a}$ & $453 \mathrm{a}$ & $387 b$ & $504 \mathrm{a}$ & $483 b$ & 3.7 & $* * *$ & $* * *$ & $* * *$ \\
\hline Acid detergent fiber & 174 & 164 & 246 & 215 & 280 & 258 & 3.9 & $* *$ & $* * *$ & ns \\
\hline Organic matter digestibility $^{(2)}$ & $0.76 \mathrm{a}$ & $0.75 \mathrm{a}$ & $0.70 \mathrm{~b}$ & $0.75 \mathrm{a}$ & $0.68 b$ & $0.70 \mathrm{a}$ & 0.004 & $* *$ & $* * *$ & $* *$ \\
\hline
\end{tabular}

${ }^{(1)}$ Means inside each cycle followed by equal letters do not differ by the t test at $5 \%$ probability. ${ }^{(2)} \mathrm{Calculated}$ from the fecal crude protein content, the fecal acid-detergent content, and the crude protein content of the offered herbage according to Ribeiro Filho et al. (2003). HLI, high-light interception (95\%); LLI, low-light interception (90\%); SE, standard error; DM, dry matter. 
canopy. The proportion of live laminae was higher and the proportion of live sheathes and stems was lower for LLI than for HLI swards. Similarly, the proportion of live laminae decreased and the proportion of live sheathes and stems increased from the first to the third cycle. Total herbage mass was higher for HLI than for LLI swards, but the live laminae of herbage mass was similar between them. The CP ratio was $38 \mathrm{~g} \mathrm{~kg}^{-1}$ higher, and the ADF ratio was $21 \mathrm{~g} \mathrm{~kg}^{-1}$ lower for LLI swards, when compared to HLI swards. In the third cycle, CP decreased $77 \mathrm{~g} \mathrm{~kg}^{-1} \mathrm{DM}$, whereas ADF increased $100 \mathrm{~g} \mathrm{~kg}^{-1} \mathrm{DM}$ in comparison to the first cycle. However, the proportion of NDF and organic matter (OM) digestibility were similar between swards for the first cycle, but for the second and third ones NDF was lower and OM digestibility was higher for the LLI swards.

The differences observed in chemical composition between treatments can be attributed to the larger amount of aerial biomass per hectare, as well as to the smaller proportion of laminae and the higher postgrazing height for HLI swards, in comparison to the LLI swards. Larger biomass values at pre grazing implies on a reduced quality of forage (Purcell et al., 2011), which could be associated to a lower proportion of leaf blades and larger proportion of stems and dead material in the canopy (McEvoy et al., 2009; Roca-Fernandes et al., 2011). Furthermore, these results confirm that younger and leafy plants have larger $\mathrm{N}$ content and better digestible OM content, and that more mature plants present higher NDF and ADF values (Hopkins \& Wilkins, 2006). For perennial ryegrass pastures, increases in $\mathrm{CP}$ content and decreases in NDF and ADF have already been observed (O'Donovan et al., 2004; Kennedy et al., 2006) as consequences for hastening date of the first grazing cycle.

Total herbage allowance did not change between swards, but increased drastically in the third cycle in comparison to the first and second ones (Table 2). Live laminae herbage allowance was similar between HLI and LLI swards in the first and third cycles, but it was higher for LLI swards in the second cycle. Post-grazing sward height was lower for LLI than for HLI swards in the first cycle and similar between swards in the second and third ones. The extended tillers and sheaths heights were lower for LLI than for HLI swards in the first and second cycles, but did not differ in the third one. Pastures with larger proportion of leaf blades in the first grazing cycle tend to maintain this characteristic and to have better digestibility in the second grazing cycle (Kennedy et al., 2007; Curran et al., 2010), whereas the quality of forage shows a greater decrease in the next grazing cycle for pastures with larger proportion of stems and dead material close to soil surface (O'Donovan et al., 2004). In terms of post-grazing height, Curran et al. (2010) found that forage quality is enhanced at subsequent grazing cycles due to lower post-grazing heights and less dead material from residual pasture left from the previous cycle.

HLI and LLI herbage intake showed no variation with sward type, but herbage digestible OM intake and metabolisable energy intake decreased as grazing cycles progressed. Milk yield was higher for LLI than for HLI swards (1.7 kg per day) and decreased throughout the cycles. Fat content of milk did not vary with treatments or grazing cycles. Live weight also did not change with treatments or grazing cycles, but protein yield was higher for LLI than for HLI in the second cycle, and it did not vary with sward type in the first and third cycles.

The similarity in herbage intake can be attributed to the fact that, for both treatments, severity of defoliation was always lower than $50 \%$ of pre-grazing height at the beginning of grazing. At this condition, animals always ingest only the higher strata of the canopy, avoiding stems, which act as a barrier to defoliation and reduce both instantaneous and daily herbage intake (Drescher et al., 2006). However, DM herbage allowance as live lamina (Table 2), during the second and third grazing cycles for HLI swards, was lower than the estimated DM intake (Table 3). This result indicates larger proportion of stems in the diets of cows in the HLI pastures.

Therefore, the larger milk yield under the LLI treatment is clearly associated to the quality of herbage intake, when compared to the HLI treatment. These results confirm the findings of O'Donovan et al. (2004), who attributed larger milk yield by cows grazing forage with larger proportion of leaf blades to a better feeding, even when the animals ingested about $1.0 \mathrm{~kg}$ DM less per cow with high requirement. Curran et al. (2010) also found increasing milk yield per $\mathrm{kg}$ of ingested herbage for decreasing pre-grazing herbage mass. Moreover, the larger protein yield by cows in LLI pastures in the second grazing cycle is closely related to animal energy balances. The effects of energy supply on protein synthesis for milk is widely known, since protein synthesis in the mammary glands is an energy-expensive process (Coulon \& Rémond, 1991). 
Table 2. Herbage allowance and effects of grazing management (GM) and grazing cycle (GC) on post-grazing sward height of Italian ryegrass (Lolium multiflorum) $^{(1)}$.

\begin{tabular}{|c|c|c|c|c|c|c|c|c|c|c|}
\hline \multirow[t]{2}{*}{ Parameter } & \multicolumn{2}{|c|}{ Cycle 1} & \multicolumn{2}{|c|}{ Cycle 2} & \multicolumn{2}{|c|}{ Cycle 3} & \multirow[t]{2}{*}{ SE } & \multicolumn{3}{|c|}{ Significance } \\
\hline & HLI & LLI & HLI & LLI & HLI & LLI & & GM & $\mathrm{GC}$ & GM vs. GC \\
\hline & \multicolumn{10}{|c|}{ Herbage allowance (kg of DM per day) } \\
\hline Total & 31.1 & 29.8 & 36.6 & 35.9 & 71.0 & 68.4 & 0.8 & ns & $* * *$ & ns \\
\hline \multirow[t]{2}{*}{ Live lamina } & $18.4 \mathrm{a}$ & $19.2 \mathrm{a}$ & $10.3 b$ & $15.6 \mathrm{a}$ & $11.6 \mathrm{a}$ & $15.2 \mathrm{a}$ & 0.7 & $* *$ & $* *$ & * \\
\hline & \multicolumn{10}{|c|}{ Post-grazing sward height $(\mathrm{cm})$} \\
\hline Rising plate meter & 3.2 & 2.4 & 4.8 & 5.2 & 5.0 & 4.7 & 0.2 & * & $* * *$ & * \\
\hline Extended tiller & $20.6 \mathrm{a}$ & $15.3 \mathrm{~b}$ & $30.1 \mathrm{a}$ & $25.2 \mathrm{a}$ & $30.5 \mathrm{a}$ & $32.7 \mathrm{a}$ & 0.7 & * & $* * *$ & * \\
\hline Extended sheath & $12.4 \mathrm{a}$ & $8.3 b$ & $27.5 \mathrm{a}$ & $19.9 b$ & $25.8 \mathrm{a}$ & $26.7 \mathrm{a}$ & 5.4 & $* *$ & $* * *$ & $* * *$ \\
\hline
\end{tabular}

${ }^{(1)}$ Means inside each cycle followed by equal letters do not differ by the t test at 5\% probability. HLI, high-light interception (95\%); LLI, low-light interception (90\%); SE, standard error.

Table 3. Effects of grazing management (GM) and grazing cycle (GC) on herbage intake and animal performance of dairy cows grazing Italian ryegrass (Lolium multiflorum).

\begin{tabular}{|c|c|c|c|c|c|c|c|c|c|c|}
\hline \multirow[t]{2}{*}{ Parameter } & \multicolumn{2}{|c|}{ Cycle 1} & \multicolumn{2}{|c|}{ Cycle 2} & \multicolumn{2}{|c|}{ Cycle 3} & \multirow[t]{2}{*}{$\mathrm{SE}$} & \multicolumn{3}{|c|}{ Significance } \\
\hline & HLI & LLI & HLI & LLI & HLI & LLI & & GM & GC & GM vs. GC \\
\hline Herbage DM intake (kg per day) & 15.9 & 15.3 & 15.3 & 14.8 & 12.9 & 14.6 & 0.45 & ns & ns & ns \\
\hline Herbage OM intake (kg per day) & 14.4 & 13.7 & 14.2 & 13.5 & 12.1 & 13.7 & 0.40 & ns & ns & ns \\
\hline Herbage DOM intake (kg per day) & 11.0 & 10.4 & 10.0 & 10.2 & 8.2 & 9.6 & 0.31 & ns & * & ns \\
\hline ME intake (Mcal per day) & 45.9 & 43.6 & 40.5 & 41.6 & 32.9 & 38.6 & 1.32 & ns & $* *$ & ns \\
\hline Milk yield (kg per day) & 23.5 & 24.3 & 18.6 & 21.7 & 16.6 & 17.2 & 0.3 & $*$ & $* * *$ & ns \\
\hline FCM yield $^{(2)}$ (kg per day) & 21.4 & 21.5 & 17.3 & 19.5 & 14.3 & 15.5 & 0.3 & $*$ & $* * *$ & ns \\
\hline Milk fat content $\left(\mathrm{g} \mathrm{kg}^{-1}\right)$ & 33.9 & 32.3 & 35.9 & 33.5 & 32.5 & 33.5 & 1.1 & ns & ns & ns \\
\hline Milk protein content $\left(\mathrm{g} \mathrm{kg}^{-1}\right)$ & 32.5 & 30.4 & 33.3 & 32.0 & 36.0 & 33.0 & 0.4 & * & $* *$ & ns \\
\hline Milk fat yield (kg per day) & 794 & 787 & 667 & 728 & 542 & 575 & 17 & ns & $* * *$ & ns \\
\hline Milk protein yield (kg per day) & $751 \mathrm{a}$ & $742 \mathrm{a}$ & $606 \mathrm{~b}$ & $691 \mathrm{a}$ & $552 \mathrm{a}$ & $567 \mathrm{a}$ & 8.2 & $*$ & $* * *$ & $*$ \\
\hline Live weight (kg) & 576 & 563 & 594 & 573 & 557 & 552 & 9.3 & ns & ns & ns \\
\hline Energy balance (Mcal per day) & $-0.9 \mathrm{a}$ & $-4.9 \mathrm{a}$ & $-5.8 b$ & $0.4 \mathrm{a}$ & $-7.3 \mathrm{a}$ & $-6.9 \mathrm{a}$ & 1.14 & ns & ns & $*$ \\
\hline
\end{tabular}

${ }^{(1)}$ Means inside each cycle followed by equal letters do not differ by the $t$ test at $5 \%$ probability. ${ }^{(2)} \mathrm{FCM}, 4 \%$ fat-corrected milk. HLI, high-light interception (95\%); LLI, low-light interception (90\%); SE, standard error; DM, dry matter; OM, organic matter; DOM, digestible organic matter; ME, metabolisable energy.

\section{Conclusions}

1. The onset of grazing when light interception of Italian ryegrass reaches $90 \%$ results in larger proportions of live lamina in the canopy and greater nutritional value in the subsequent cycles.

2. Better quality of herbage throughout the pasture growth cycle allows for increasing fat-corrected milk yields by dairy cows, regardless of herbage intake variations.

\section{Acknowledgments}

To Conselho Nacional de Desenvolvimento Científico e Tecnológico for financial support.

\section{References}

BAKER, R.D. Estimating herbage intake from animal performance. In: PENNING, P. Herbage intake handbook. $2^{\text {nd }}$ ed. Reading: The British Grassland Society, 2004. p.95-120.

COULON, J.B.; RÉMOND, B. Variations in milk output and milk protein content in response to the level of energy supply to the dairy cow: a review. Livestock Production Science, v.29, p.31-47, 1991.

CURRAN, J.; DELABY, L.; KENNEDY, E.; MURPHY, J.P.; BOLAND, T.M.; O'DONAVAN, M. Sward characteristics, grass dry matter intake and milk production performance are affected by pre-grazing herbage mass and pasture allowance. Livestock Science, v.127, p.144-154, 2010.

DELABY, L.; PEYRAUD, J.-L.Valoriser les fourrages de l'exploitation pour produire du lait. Fourrages, v.198, p.191-210, 2009. 
DRESCHER, M.; HEITKONIG, I.M.A.; RAATS, J.G.; PRINS, H.H.T. The role of grass stems as structural foraging deterrents and their effects on the foraging behaviour of cattle. Applied Animal Behaviour Science, v.101, p.10-26, 2006.

HOPKINS, A.; WILKINS, R.J. Temperate grassland: key developments in the last century and future perspectives. Journal of Agricultural Science, v.144, p.503-523, 2006.

HORWITZ, W. (Ed.). Official methods of analysis of AOAC International. $17^{\text {th }}$ ed. Gaithersburg: AOAC International, 2000. $2 \mathrm{v}$.

KENNEDY, E.; O’DONOVAN, M.; MURPHY, J.P.; DELABY, L.; O'MARA, F.P. Effect of spring grazing date and stocking rate on sward characteristics and dairy cow production during midlactation. Journal of Dairy Science, v.90, p.2035-2046, 2007.

KENNEDY, E.; O'DONOVAN, M.; MURPHY, J.P.; O'MARA, F.P.; DELABY, L. The effect of initial spring grazing date and subsequent stocking rate on the grazing management, grass dry matter intake and milk production of dairy cows in summer. Grass and Forage Science, v.61, p.375-384, 2006.

LITTELL, R.C.; HENRY, P.R.; AMMERMAN, C.B. Statistical analysis of repeated measures data using SAS procedures. Journal of Animal Science, v.76, p.1216-1213, 1998.

MCEVOY, M.; O'DONOVAN, M.; KENNEDY, E.; MURPHY, J.P.; DELABY, L.; BOLAND, T.M. Effect of pregrazing herbage mass and pasture allowance on the lactation performance of Holstein-Friesian dairy cows. Journal of Dairy Science, v.92, p.414-422, 2009.

O'DONOVAN, M.; DELABY, L.; PEYRAUD, J.L. Effect of time of initial grazing date and subsequent stocking rate on pasture production and dairy cow performance. Animal Research, v.53, p.489-502, 2004.

PEYRAUD, J.L.; COMERON, E.A.; WADE, M.H. The effect of daily herbage allowance, herbage mass and animal factors upon herbage intake by grazing dairy cows. Annales de Zootechnie, v.45, p.201-217, 1996.

PURCELL, P.J.; O'BRIEN, M.; BOLAND, T.M.; O'DONOVAN, M.; O'KIELY, P. Impacts of herbage mass and sward allowance of perennial ryegrass sampled throughout the growing season on in vivo rumen methane production. Animal Feed Science and Technology, v.166-167, p.405-411, 2011.

RIBEIRO FILHO, H.M.N.; DELAGARDE, R.; PEYRAUD, J.L. Inclusion of white clover in strip-grazed perennial ryegrass swards: herbage intake and milk yield of dairy cows at different ages of sward regrowth. Animal Science, v.77, p.499-510, 2003.

ROBERTSON, J.B.; VAN SOEST, P.J. The detergent system of analysis and its application to human foods. In: JAMES, W.P.T.; THEANDER, O. (Ed.). The analysis of dietary fiber in food. New York: Marcel Dekker, 1981. p.123-158.

ROCA-FERNANDEZ, A.I.; O'DONOVAN, M.A.; CURRAN, J.; GONZALEZ-RODRIGUEZ, A. Effect of pre-grazing herbage mass and daily herbage allowance on perennial ryegrass swards structure, pasture dry matter intake and milk performance of Holstein-Friesian dairy cows. Spanish Journal of Agricultural Research, v.9, p.86-99, 2011.

VAN SOEST, P.J.; ROBERTSON, J.B.; LEWIS, B.A. Methods for dietary fiber, neutral detergent fiber, and nonstarch polysaccharides in relation to animal nutrition. Journal of Dairy Science, v.74, p.3583-3597, 1991.

$\overline{\text { Received on November 18, } 2011 \text { and accepted on April 26, } 2012}$ 